\title{
CARTAS CHILENAS: THE PSEUDOTRANSLATION OF TOMÁS GONZAGA
}

\author{
John Milton
}

\section{The Inconfidência Mineira}

The Inconfidência Mineira of 1789 was a Brazilian independence movement in the gold mining state, or captaincy [capitania], as it was called at the time, of Minas Gerais, Brazil. The Inconfidentes were a loose group of friends and business associates, mostly coming from what Maxwell describes as the plutocracy of Minas Gerais (Maxwell 1995, p. 119), who were upset by the Derrama, the proposal made by the Portuguese Governor of the Capitania of Minas Gerais from 1783-1788, Luís Cunha de Meneses (1743-1819), to obtain the outstanding taxes that were owed to the Portuguese crown as a result of gold mining. In addition, there was considerable resistance to the autocratic habits of the Governor. Cláudio Manuel da Costa and Tomás Antônio Gonzaga, both lawyers and poets, were especially angered by the fact that Cunha Meneses took away from the magistrates the special and lucrative powers of debt collection and conceding mortgages.

Tomás Antônio Gonzaga (1744-1810) was the Ouvidor [Judge] in Vila Rica. He was the son of one of the confidants of Pombal. His father had been born in Brazil and was a magistrate who had been Ouvidor in Pernambuco, and who had occupied important posts in Bahia and Porto, Portugal. Gonzaga had been named Visiting Judge [Juiz de Fora] of Beja in Portugal in 1779 and Ouvidor in Vila Rica in 1782. He was also a recognized poet (Maxwell 2005, p. 117) and was only able to publish a critique of the hated Luís Cunha de Menezes, by adapting the poem - changing the references, and pretending that he had not written it, in other words, by making it into a pseudotranslation.

\section{Translation in the Minas Conspiracy}

In "The Important Role of Translation in the 1789 Brazilian Minas Conspiracy" (Milton \& Hirsch 2014) I examined the role of translation in the Inconfidência Mineira (Minas Conspiracy). I showed that at a number of levels translation had an important role to play. Firstly, a copy of Claude Ambrose Régnier's Recueil des Lois Constituives enabled the rebels, the Inconfidentes, to become familiar with the constitution of the 
United States and the laws of the thirteen states. This copy, which belonged to Tiradentes, the most famous Inconfidente, was passed around from hand to hand, and Tiradentes asked his friends and associates to translate sections. Whilst translating these sections Tiradentes hoped that the translator would become interested in the laws and basic concepts of an independent free-standing country, which had rid itself of domination and interference from its colonizer. Thus initially we find Tiradentes depending on what has become known as Natural Translation, translation practiced in informal settings by nonqualified translators, usually members of the family and friends, but with the design of winning over the translators to the causes of the Inconfidentes.

Many of the Inconfidentes were members of the intellectual elite of Ouro Preto, read foreign literature, usually in French, and translated. Cláudio Manuel da Costa, for example, is reported to have translated Adam Smith's Wealth of Nations though no copy is extant (Maxwell 2005, p. 147). The history of the Recueil, which is now on display in the Museu da Inconfidência in Ouro Preto, was also dealt with. Surprisingly, it was only translated into Portuguese in 1981.

Finally, I looked at translation as representation and analyze the way in which the hanging of Tiradentes has been represented in Brazil and show how he became an iconic figure in Brazilian history. This article did not cover Cartas Chilenas.

\section{Pseudotranslations}

Gideon Toury gives a number of examples of pseudotranslations: he quotes Dmitri Shostakovitch's account of an old Kazakh folk singer called Dzhambul Dzhabayev during Stalin's regime in the Soviet Union, whose traditional songs were "translated" by "“an entire brigade of Russian poetasters' who, in turn, didn't know any Kazakh” (Toury 1995, p. 44), but they did know the right kind of poem that was necessary in order to please the Stalinist authorities. Toury also mentions Papa Hamlet, a pseudotranslation "translated" from the Norwegian, published in Leipzig, which enjoyed considerable popularity and actually functioned as an original for several months in 1889 before the authorship of German writers, Arno Holz (1863-1929), and Johannes Schlaf (1862-1941), was discovered.

Other cases of well-known pseudotranslations are Don Quijote, the majority of which Cervantes purports to have translated from the Arabic of the Moorish author Cid Hamet Ben Engeli; Lord of the Rings, supposedly a translation from Elvish; Horace Walpole's 1764 Gothic novel, The Castle of Otranto, stated to be a translation based on 
a manuscript printed at Naples in 1529 and recently rediscovered in the library of "an ancient Catholic family in the north of England"; and possibly the most noteworthy pseudotranslation of all, James Macpherson's Ossian (1760), the cycle of epic poems which Macpherson claimed to have collected as traditional oral stories in Scots Gaelic and then translated them into English.

Anikó Sohár documents some of the many pseudotranslations made in Hungary in the post-socialist period from 1989 to 1995 (in Milton 2002, p. 127-9). She began to research an American cyberpunk author, Wayne Chapman, born in Concord, Massachusetts, and who had also published with Pendragon Publishing Co. Inc., London, only to discover that Wayne Chapman was a mere invention, and the owners of the small Hungarian publishing house, Valhalla Páholy, András Gáspár and Csanád Novák, had actually been the authors of the works. Sohár gives many more examples in the areas of science and fantasy fiction (Sohár 1999).

We can differentiate pseudotranslations such as Lord of the Rings and Don Quijote, where presenting a work as a pseudotranslation is used as a literary technique, a frame to distance the work from the writer, and maybe, as in the case of Quijote, anticipating possible censorship, but with the reader never really believing the work is really a translation. Apart from hardcore Tolkien fans, there are few that believe that Lord of the Rings was actually translated from Elvish.

In the case of Ossian, Macpherson's invention of the Scots Gaelic poems was an attempt to further his literary career, as were the pseudotranslations made by the "Russian poetasters" mentioned by Toury. Such pseudotranslations are meant to deceive, for professional or financial reasons, as is the case of the commercial pseudotranslations in Hungary which Anikó Sohár mentions.

The Cartas Chilenas clearly belong to the first type. They circulated in pamphlet form in Minas Gerais during Meneses' government, and the parallels with the situation in Minas Gerais during the government of Meneses are very clear, and no one with the least knowledge of contemporary Minas could have believed that it was actually a translation. Indeed, it seems that Gonzaga was writing for a coterie of friends and acquaintances, and he also hoped that the Cartas would find their way to the Portuguese court. They do not criticize Portuguese rule in Brazil itself, merely the abuses of Meneses. The pseudotranslation technique is no more than an insurance policy against possible reprisals. If questioned by the Portuguese authorities, Gonzaga could say that the Cartas Chilenas were actually a translation. 


\section{The Cartas Chilenas}

The Cartas Chilenas [Chilean Letters] are a satirical poem composed in blank verse, a total of 4268 lines, in 13 "cartas", supposedly written in Santiago, Chile, by Critilo, to his friend, Doroteu, criticizing the behaviour and governance of the administration of the Governor of Santiago, Fanfarrão Minésio. The frontispiece gives the following information (Gonzaga 1996, p. 23):

Cartas Chilenas. Em que o Poeta Critilo conta a Doroteu os Fatos de Fanfarrão Minésio, Governador de Chile. Escritas em espanhol pelo poeta Critilo. Traduzidas em português e dedicadas aos Grandes de Portugal por uma Pessoa Anônima.

["Letters from Chile. In which the Poeta Critilo tells Doroteu the facts relating to Fanfarrão Minésio, Governor of Chile. Written in Spanish by the poet Critilo. Translated into Portuguese and dedicated to the Great of Portugal by an Anonymous Person"].

The Prologue, written by the anonymous "translator", frames the pseudotranslation. A galleon coming from Spanish America docked in Brazil, and a manuscript containing the Cartas Chilenas was confided to the translator, who, as soon as he read them, decided to translated them into Portuguese "[...] pelo benefício, que se resulta ao público, de se verem satirizadas as insolências deste Chefe para emenda dos mais, que seguem tão vergonhosas pisadas" ["for the benefit which comes to the public of seeing the insolence of this Boss satirized, and for the notice of others who follow such shameful steps"] (Gonzaga 1996, p. 26).

There is no doubt that the poem refers to the administration of Luís da Cunha Meneses, Governor of the Capitania of Minas Gerais from 1783 to 1788 . The poem is dedicated to the "Great of Portugal", who the poet hopes will be able to learn from the example of the low deeds of Fanfarrão Minésio, discovered in a foreign land. Certain references are very specific. One is the reference to the wasteful construction of the Casa da Câmara [Council House] and Prison of Vila Rica, today the Museu da Inconfidência [Conspiracy Museum], and which appears in Cartas 3 and 4.

Likewise, the cryptonyms are easy to decipher: Menezes is "Minésio"; Roberto Antônio de Lima, Meneses' servant who was promoted to sergeant in the auxiliary militia, is "Robério"; Joaquim Silvério dos Reis, tax collector on goods entering the Minas Gerais and colonel in the auxiliary militia, and later the Inconfidencia conspirator who became 
the main informer, is "Silverino"; and José Pereira Marques, another tax collector and captain in the militia, is "Marquésio".

In Carta 5 Chile is, like Minas Gerais, mentioned as being a gold-mining area. The feasts which are described in Cartas 5 and 6 bear a strong resemblance to the wedding celebrations of the Portuguese prince, Dom João, to the Spanish princess, Dona Carlota Joaquina, which were held in Vila Rica in May 1786 (Furtado 1997, p. 68). There are clear references to the Derrama in Carta 7. The excesses of Minésio in his establishment of auxiliary militias, for which he was reprehended by Lisbon, appear in Carta 9 (Gonzaga 1996, p. 129):

\begin{abstract}
Não há, não há distúrbio nesta terra,
De que mão militar não seja autora.

["There is no, there is problem in this land, Which a military hand is not behind"]
\end{abstract}

In addition, a number of topographical features of Vila Rica can be recognized, and other inhabitants of Vila Rica are lightly disguised (Furtado 1995, p. 10).

The tone of the Cartas Chilenas is always quite vehement. The following section is from Doroteu's introductory "Epístola a Crítilo", probably written by Cláudio Manuel da Costa (Carta 1, Gonzaga 1996, p. 34):
Aqui se acha o lascivo, é o vaidoso,
É o estúpido, enfim é o demente,
O que ao vivo aparece nesta empresa.
["Here you find the lascivious, the vain,
The stupid, the demented.
Who appears live in this enterprise."]

One of the techniques of Arcadismo was to use techniques coming from the satires of Juvenal to exaggerate the physical characteristics of the subject of the satire. Thus Fanfarrão Minésio is physically repugnant and animalistic (Carta 1, Gonzaga 1996, p. 38):

Feições compridas, e olhadura feia,

Tem grossas sobrancelhas, testa curta,

Nariz direito, e grande; fala pouco

Em rouco baixo tom de mau falsete

$[\ldots]$

Ainda me parece, que o estou vendo

No gordo rocinante escarranchado! 
[Long features, and ugly look,

He has thick eyebrows, a low forehead,

A straight big nose; he speaks little

In a hoarse low tone of a bad falsetto

$[\ldots]$

And it seems to be that I'm seeing him

Mounted on the fat old nag!

He is also lascivious, bestial, venial, insane, open to bribery and flattery; he is spendthrift, capricious in his administration; he is surrounded by sycophants and favours those who deserve no favours; he ignores also protocol.

Assim o nosso Chefe não descansa

De fazer, Doroteu, no seu Governo

Asneiras, sobre asneiras: e entre as muitas,

Que menos violentas nos parecem,

Pratica outras, que excedem muito, e muito

As raias dos humanos desconcertos.

["So our Boss never stops

Doing, in his government, Doroteu,

Stupid things: and among the many,

Which less violent seems to us,

He does others, which are much worse and

Outside normal human behaviour."]

(Carta 10, Gonzaga 1996, p. 142-3)

É qual mulher ciosa, que não pode

Vingar no vário amante os duros zelos,

E vai desafogar as suas iras

Bebendo o sangue de inocentes filhos.

["He's like the woman, who cannot

Revenge her jealousy on her wandering lover,

And who unleashes her anger

By drinking the blood of innocent children."']

(Carta 10, Gonzaga 1996, p. 145)

Occasionally, references to Chile are brought in to remind us that the governor of Santiago and not Minas Gerais, is being criticized. However, no references are made to Chile other than its name:

Ah pobre Chile! Que desgraças esperas!

Quanto melhor te fora, se sentisses

As pragas, que no Egito se choraram,

Do que veres, que sobe ao teu Governo

Carrancudo casquilho, a quem rodeiam 
Os néscios, os marotos, e os peraltas.

[“Ah, poor Chile! What misfortunes await you!

How much better it would be, if you felt

The plagues, which in Egypt wept,

Which you will see, and which climb up to your government,

You haughty dandy, surrounded by

Fools, rogues, and idlers."]

(Carta 1, Gonzaga 1996, p. 41)

For many years the authorship of the Cartas Chilenas was unsure, and fellow conspirators Cláudio Manuel da Costa and Alvarenga Peixoto were also contenders for authorship. However, the detailed philological study by Manuel Rodrigues Lapa, "As "Cartas chilenas": um problema histórico e filológico" ["The Chilean Letters": a historical and philological problem] (in Gonzaga 1996, p. 12-13) pointed out various stylistic similarities between this work and Marília de Dirceu and Tratado do direito natural, also by Gonzaga, with the short Preface being that of Cláudio Manuel da Costa (Furtado in Gonzaga 1997, p. 33), who is also the addressee, Doroteu. Gonzaga and Meneses were enemies, firstly, as previously mentioned, because Meneses took away from Gonzaga the lucrative contract to receive taxes from the goods entering Minas Gerais, Gonzaga eventually being removed from his post in 1788. On the discovery of the Conspiracy, Gonzaga was waiting to take up a similar post in Bahia and marry his beloved muse, Maria Dorotéia, immortalized in his sequence of poems to "Marília". Gonzaga had officially complained to the Portuguese Queen twice, in 1784 and 1787, about Meneses' behaviour, and it seems that the Cartas Chilenas are much more of a personal critique of the abuses of Meneses, who had upset the gentlemen's agreement between the local elite and the Portuguese government than a proto-Republican document (Furtado 1997: 82). There are also stylistic similarities with other of his works, especially Marília de Dirceu and Tratado de Direito Natural (Furtado in Gonzaga 1995, p. 12).

Quite obviously, Gonzaga had to disguise the Cartas Chilenas as a pseudotranslation because of "censorial measures against himself or his work" (Toury 1995, p. 42) would result from the "ilegalidade da redação e circulação de 'pasquins', a virulência dos ataques à administração e à pessoa de Minésio e a ridicularização de seus auxiliares" ["the illegality of the authoring and circulation of satirical leaflets, the virulence of attacks on the administration, and the ridiculing of his auxiliaries"] (Furtado 1997, p. 39), and they were probably passed from hand to hand in Vila Rica. There is no 
evidence that Meneses actually read them, heard about them, or that knowledge of their existence reached the Portuguese crown in Lisbon (Furtado 1997, p. 75).

Though recent work such as those by Maxwell (1973/2005) and João Furtado (2002) have pointed much more to personal economic factors being the main factor behind the Conspiracy, the Cartas Chilenas were taken by many Brazilian literary critics, particularly during the Romantic period, when Gonzaga, rather than Tiradentes, was seen as the hero of the Conspiracy, as a founding document of the concept of Brazilian nationality. This tone was set by the 19th century critic Sílvio Romero, who saw Gonzaga's satire as “o brado da raça oprimida contra os antigos conquistadores, uma queixa contra essa flagrante injustiça da natureza e da história, que condena certas raças à impotência, como povos inferiores" ["the protest of the oppressed race against the former conquerors, a complaint against this flagrant injustice of nature and history, which condemns certain races to impotence, as inferior peoples"] (in Furtado 1997, p. 105). Indeed, my previously published article (Milton \& Hirsch 2014) showed that Gonzaga was seen as the most important figure in the Conjuração before the Republic (1888), as in Gonzaga ou a Conjuração de Tiradentes (1848), a novel by Antônio Ferreira de Sousa, and in the play Gonzaga ou a Revolução de Minas (1866) by the Romantic poet Castro Alves and performed in the same year in São Paulo, Salvador and Rio de Janeiro (Furtado 1995, p. 103). By contrast, the Republic adopted Tiradentes as the national Brazilian hero.

\section{The failure of the Inconfidência Mineira}

The Inconfidentes were strongly influenced by the American Revolution and also the works of Raynal, particularly his strongly anti-colonialist Historic philosophique et politique des établissements et du commerce des Européens dans les deux Indes (1770), which proposed the right of the people to revolt and to give or withhold consent to taxation. (Maxwell 2005, p. 151-2). They believed that a break with Portugal would both improve their own positions and help for economic expansion. In December 1788 they began to sketch their ideas for the new republic. With the Derrama, it would be easy to attract the support of all sectors of society, and the business sector in particular was strongly against the enormous restrictions which the Portuguese crown placed on Brazilian manufacturing. The capital of the new Republic would be São João d'El Rey, a mint would be set up, and the exchange rate fixed at $1 \$ 200$ réis por oitavo de ouro, which would end the shortage of money. The restrictions on the diamond industry would be lifted, and manufacturing industries and a gunpowder factory would be established. 
Slaves born in Brazil would be freed; and a university would be opened in Vila Rica. The Catholic Church would receive funds for hospitals and homes through tithes. Minas Gerais needed to be populated, and women who had lots of children would be rewarded. And, following the American Constitution, no national army would be set up, but the citizens would join a national militia when required. There would be a parliament in each town, which would be subject to a general parliament in the capital. Gonzaga would be the governor for three years, and then elections would take place. There would be no difference between clothing, and everyone should wear locally produced clothes, thereby stimulating the local textile industry. And for Maxwell, most importantly of all, all debtors to the Royal Treasury in Portugal would be pardoned.

In June 1788 the Portuguese replaced the Governor Cunha de Meneses, maybe to a certain extent through the popularity of the Cartas Chilenas, with the more sensitive and cautious Conde de Barbacena, who, aware of the revolt that the Derrama might cause, suspended it in June 1788. In February 1790, Barbacena was given information about the Inconfidência plans by the informer Joaquim Silvério dos Reis (1756-1792), the "Silverino" of the Cartas Chilenas, who probably saw the information that he gave as a way of escaping from his own debts.

In June and July 1790 the crown forces were called in from Rio de Janeiro to take over Vila Rica. Tiradentes was captured and imprisoned, as were the other Inconfidentes. Cláudio Manuel da Costa died, apparently committing suicide after two days in a makeshift prison, though this version is contested (see Crux vol. 2, p. 109-160) and the other Inconfidentes were imprisoned in Rio de Janeiro until their trial. So the revolt, the Inconfidência, never actually took place.

The sentence was finally pronounced on 18 April 1792 in Rio de Janeiro, taking some 18 hours. Tiradentes was condemned to be hung, drawn and quartered, and the parts of his body would be taken to Vila Rica, where his head would be impaled in the centre of the town and parts of body exhibited along roads leading to Rio. His house in Rio should be destroyed and land salted. Other conspirators, Freire de Andrade, Álvares Maciel, Alvarenga Peixoto, Oliveira Lopes and Luís Vaz should also be hung, drawn and quartered, and the remaining Inconfidentes exiled to Africa. Then, theatrically, a letter from the Queen of Portugal was read out to pardon them all except Tiradentes, who was hanged on the morning of 21 April 1792 in the centre of Rio de Janeiro (Maxwell 2005, p. 221-2). 
The priests, Padre Rolim, Padre Luís Vieira da Silva, and Padre Carlos Correia de Toledo were imprisoned in Lisbon until 1796. Alvarenga Peixoto, Francisco de Paula Freire de Andrade, and José Álvares Maciel were all exiled to Angola. There Maciel became friends with the governor and exploited iron mines, becoming owner of one of the most important smelting factories. Gonzaga was exiled to Mozambique, where he helped the sick Ouvidor, José da Costa Dias Barros, then became the civil servant responsible for deaths and absences, and in 1793 married the rich widow, Juliana de Sousa Mascarenhas, with whom he had two children. His Marília de Dirceu became very popular in both Portugal and Brazil, with six editions being published in his lifetime.

\section{References}

CRUX RODRIGUES VIEIRA, José. Tiradentes: A Inconfidência diante da História (2 volumes). Belo Horizonte: $2^{\circ}$ Clichê Comunicação \& Design Ltda, 1993.

FURTADO, Joaci Pereira. Uma república de Leitores: História e Memória na Recepção das Cartas Chilenas (1845-1989). São Paulo: Hucitec, 1997.

FURTADO, João Pinto. O Manto de Penélope: História, mito e memória da Inconfidência Mineira de 1788-9. São Paulo: Companhia das Letras, 2002.

GOnZAGA, Tomás Antônio. Cartas Chilenas. Ed. Joaci Perreira Furtado. São Paulo: Companhia das Letras, Companhia de Bolso, 1996.

MAXWELL, Kenneth. A Devassa da Devassa: A Inconfidência Mineira: BrasilPortugal - 1750-1808. 6a. ed. Trad. João Maia. São Paulo: Paz e Terra, 2005. Originally published as Conflicts and Conspiracies: Brazil \& Portugal 1750-1808. Cambridge: Cambridge University Press, 1973.

MILTON, John; HIRSCH, Irene. The Important Role of Translation in the 1789 Brazilian Minas Conspiracy. In BOASE-BIER, Jean; FAWCETT, Antoinette; WILSON, Philip. Literary Translation: Redrawing the Boundaries. London: Palgrave Macmillan, 2014. p. 217-240.

RODRIGUES LAPA, Manuel. As "Cartas chilenas": um problema histórico e filológico. Rio de Janeiro: Instituto Nacional do Livro. 1958

SOHÁR, Anikó. The Cultural Transfer of Science Fiction and Fantasy in Hungary

1989-1995. Peter Lang: Frankfurt/M., Berlin, Bern, Bruxelles, New York, Wien, 1999. 
MILTON - Cartas Chilenas: the Pseudotranslation of Tomás Gonzaga

TOURY, Gideon. Descriptive Translation Studies and Beyond. Amsterdam: John Benjamins, 1995. 